\title{
Evaluation of nitrogen and phosphorus wastes produced by Nile tilapia (Oreochromis niloticus L.) fed Azolla-diets in concrete tanks
}

\author{
Youssouf ABOU ${ }^{1 *}$, Emile D. FIOGBE ${ }^{1}$, Martin P. AINA ${ }^{2}$, André BULDGEN ${ }^{3}$ \\ and Jean-Claude MICHA ${ }^{4}$ \\ ${ }^{1}$ Unité de Recherche sur les Zones Humides, Faculté des Sciences et Techniques, Département de Zoologie et \\ Génétique, Université d'Abomey-Calavi, Cotonou, Bénin. \\ ${ }^{2}$ Département de Génie Civil, Ecole Polytechnique d'Abomey-Calavi, Université d'Abomey-Calavi, Cotonou, \\ Bénin. \\ ${ }^{3}$ Unité de Zootechnie, Faculté universitaire des Sciences Agronomiques de Gembloux, Gembloux, Belgium \\ ${ }^{4}$ Research Unit in Organismic Biology, URBO/FUNDP-University of Namur, 61, rue de Bruxelles, 5000 \\ Namur, Belgium. \\ *Corresponding auteur, E-mail: y_abou@yahoo.com, Tél: 0022995422775
}

\begin{abstract}
Nitrogenous $(\mathrm{N})$ and phosphorus $(\mathrm{P})$ wastes discharged into water by Nile tilapia Oreochromis niloticus L. (initial mean weight: $16.4 \mathrm{~g}$ ) fed in tanks for 90 days was studied. Fish were fed with six isonitrogenous ( $29.2 \%$ crude protein) and isoenergetic $\left(16.9 \mathrm{Kj} \mathrm{g}^{-1}\right)$ diets $\mathrm{A}_{0}, \mathrm{~A}_{10}$, $\mathrm{A}_{20}, \mathrm{~A}_{30}, \mathrm{~A}_{40}$ and $\mathrm{A}_{50}$, containing $0 \%, 10 \%, 20 \%, 30 \%, 40 \%$ and $50 \%$ of Azolla meal (AM) respectively, as partial fishmeal (FM) substitutes. Diet $\mathrm{A}_{0}$, without $\mathrm{AM}$, served as a control. Growth performances were higher with the control diet, and a decreasing trend was found when AM level was higher than $10 \%$ in diets $(P<0.05)$. Identical values were recorded for crude protein and $\mathrm{P}$ content in fish. The total P (TP) discharged as waste show identical values (89.6-91.2 \% supplied) for all experimental fish; while total $\mathrm{N}(\mathrm{TN})$ discharged (69.5\%-80.7\% supplied) increased significantly when AM level was greater than $20 \%$ in diets $(P<0.05)$. This study indicate that AM could be used up to $10 \%$ in diets without adverse effects on growth performances. High AM in diets affects growth but high amounts of undigested $\mathrm{N}$ from AM-protein is wasted and provided to water. However, the results suggest further investigations on the use of AM in diets that sustain growth and reduce $\mathrm{P}$ waste for eutrophication alleviation.

(C) 2010 International Formulae Group. All rights reserved.
\end{abstract}

Keywords: Azolla, fish meal replacement, Oreochromis niloticus, nitrogen, phosphorus, nutrient balance.

\section{INTRODUCTION}

The rapid growth in world aquaculture production over the past few decades has resulted in a concomitant increase in demand for fish meal (FM). Because of the stable production of that feed ingredient at around 6.5 million tonnes, Hardy (2000) estimates that the amount required would be approximately 1.3 million tonnes less than 2.8 million tonnes required for aquaculture in 
2010. Limited availability of FM will subsequently represent a constraint for the growth of aquaculture production. Therefore, it is necessary to seek acceptable substitutes for this important ingredient. Another problem that could limit its sustainability is the negative impact of aquaculture on the environment due to FM. Indeed, the intensification of production results in the release of organic wastes and inorganic nutrients, such as phosphorus $(\mathrm{P})$ and nitrogen $(\mathrm{N})$, which are known to enrich and promote eutrophication in aquatic ecosystems (GESAMP, 1996). Therefore, environmental pollution associated with aquaculture practices becomes a critical issue for sustainability and expansion of this enterprise. In aquaculture, both $\mathrm{P}$ and $\mathrm{N}$ elements originate mainly from fish feeds (Cho and Bureau, 1997), due to their high levels in FM. Limited utilization of dietary $\mathrm{P}$ is often reported in fish lacking a stomach, such as common carp Cyprinus carpio L. and gibel carp Carassius auratus gibelio (Ogino et al., 1979; Zhang et al., 2006) in which high amount of unavailable dietary $\mathrm{P}$ is discharged as particulate matter in faeces (Steffens, 1989). Similarly, the excessive available dietary $\mathrm{P}$ can also be rapidly eliminated in dissolved form, probably through the gills and kidneys, as Nakashima and Leggett (1980) reported in rainbow trout Onchorhynchus mykiss Walbaum. Therefore, one should balance appropriately this nutrient in feed for farmed species. Whatever the physiological response of reared fish to dietary $\mathrm{P}$, one of the numerous ways to reduce $\mathrm{P}$ waste produced by aquaculture is the use of FM substitutes that contain less $\mathrm{P}$ with high bioavailable proportion (Cho and Bureau, 2001). Among the most popular alternative ingredients used as FM substitutes, plant proteins are found to be worthwhile to meet this goal. The importance of the use of vegetable sources as FM substitutes is widely demonstrated in many fish growth studies (Fasakin et al., 2001; Afuang et al., 2003; Fiogbé et al.,
2004). But their role in developing lowpolluting feeds by reducing $\mathrm{P}$ waste by fish is scarcely evoked. In that area, successful results had been reported by Jahan et al. (2003) in common carp and Nakashima and Leggett (1980) in rainbow trout. Also, a reduced $\mathrm{P}$ discharge has been demonstrated in fish fed diets in which FM was replaced by corn gluten meal (Kaushik et al., 2004). Of the various aquatic macrophytes that have been used with success in fish feeding, the freshwater fern Azolla can be cited (Leonard et al., 1998; Fasakin et al., 2001; Fiogbé et al., 2004). P content in Azolla species is lower than $0.77 \%$ dry matter (Leonard, 1997), which is by far lower to the level (2-4\%) generally found in FM. This may encourage testing Azolla in developing low-polluting feeds. So far, Azolla research in fish farming is strongly focused on growth performance and digestibility in O. niloticus and Oreochromis aureus Steindachner (Leonard, 1997; Leonard et al., 1998; Micha and Leonard, 2001-2). Studies on its use as an "environmentallyfriendly" ingredient are very scarce.

Therefore, the main purpose of this study was to investigate $\mathrm{P}$ and $\mathrm{N}$ wastes discharged into water by Nile tilapia $O$. niloticus fed with diets containing gradual levels of AM as FM partial substitutes.

\section{MATERIALS AND METHODS}

\section{Fish, diets and feeding regimes}

The experiment was carried out during 90 days in station $\left(6^{\circ} 25^{\prime} 1.53^{\prime \prime} \mathrm{N} 2^{\circ} 20^{\prime} 42.2^{\prime \prime} \mathrm{E}\right)$ located at the University of Abomey-Calavi, Benin (West Africa). Male Nile tilapia $O$. niloticus (initial mean weight $=16.4 \mathrm{~g}$ ) from a same cohort was bought from Lassissi fish farming centre (Porto-Novo, Benin). Sixty male fingerlings were stocked in each of eighteen 6001 square concrete tanks. These tanks were exposed to natural conditions (32$35^{\circ} \mathrm{C}$; 12-h:12-h dark diurnal photoperiod) and were subjected to an enclosed recirculating system with a water flow rate of $21 \mathrm{~min}^{-1}$. They were randomly assigned to six 
groups, each in three replicates (6 x 3 tanks), attributed to one of the diets.

Experimental diets were six isonitrogenous $(29.2 \%$ crude protein) and isoenergetic (16.9 $\mathrm{kJ} \mathrm{g}^{-1}$ ), formulated to contain $0 \%\left(\operatorname{diet} \mathrm{A}_{0}\right), 10 \%\left(\operatorname{diet} \mathrm{A}_{10}\right), 20 \%$ $\left(\operatorname{diet} \mathrm{A}_{20}\right), 30 \%\left(\operatorname{diet} \mathrm{A}_{30}\right), 40 \%\left(\operatorname{diet} \mathrm{A}_{40}\right)$ and $50 \%$ (diet $\mathrm{A}_{50}$ ) of AM using locally available ingredients and the freshwater fern Azolla filiculoides Lamarck. The control diet $\mathrm{A}_{0}$ is a practical diet used for production of marketedsize tilapia in Songhai centre (Porto-Novo, Benin). Formulation and proximate biochemical composition of experimental diets are given in Table 1. One-half liter of hot water with dissolved binder (cassava starch, obtained by cassava processing and bought in local market) was added to one kilogram of the diet thus formulated and mixed. The dough obtained was cut into paste and sundried for about three days at $32-35{ }^{\circ} \mathrm{C}$. After drying, the diet was broken into small particles $(5 \mathrm{~mm})$ and preserved in refrigerator $\left(+4^{\circ} \mathrm{C}\right)$ until used for feeding fish.

Fish were fed every day according to Melard (1986). Daily rations were divided into two parts, each hand-distributed at 8:00 h and 16:00 h, respectively. They were adjusted every two weeks according to the fish biomass in each tank.

\section{Biochemical analysis}

At the beginning of the experiment, thirty fish from the initial batch and six fish per tank at the end were randomly taken and mashed using a Robot coupe food processor. Subsamples were taken and stored at $-20^{\circ} \mathrm{C}$ for carcass analysis. The diets used were also preserved at $-20^{\circ} \mathrm{C}$ for biochemical analysis. Diets and whole fish were analyzed for dry matter (AOAC, 1990), crude protein (Nitrogen x 6.25, Kjeldahl method), crude fat (Folch et al., 1957) and crude ash content (incineration at $550^{\circ} \mathrm{C}$ in a furnace). Carcass $\mathrm{N}$ and $\mathrm{P}$ content in Azolla and diets were determined by persulphate digestion (Gross and Boyd, 1998) with boric acid and sodium hydroxide.

\section{Calculations}

Growth and feed performance parameters were calculated as follow:

Final mean weight $\left(\mathrm{W}_{\mathrm{f}}\right.$, in $\left.\mathrm{g}\right)=\mathrm{FB}(\mathrm{g}) /$ number of fish harvested

Growth rate $\left(\mathrm{g} \mathrm{day}^{-1}\right)=\left(\mathrm{W}_{\mathrm{f}}-\mathrm{W}_{\mathrm{i}}\right)$ day $^{-1}$

Specific growth rate $\left(\mathrm{SGR}, \%\right.$ day $\left.^{-1}\right)=$ $100\left[\ln \left(\mathrm{W}_{\mathrm{f}}\right)-\ln \left(\mathrm{W}_{\mathrm{i}}\right)\right]$ day $^{-1}$

Food conversion ratio $(\mathrm{FCR})=\mathrm{TFI} \mathrm{x}$ $(\mathrm{FB}-\mathrm{IB})^{-1}$

Protein efficiency ratio $(\mathrm{PER})=(\mathrm{FB}-$ IB) $\mathrm{DPI}^{-1}$

Apparent protein utilization (APU, \%) = $100 \times$ TPG $\times \mathrm{DPI}^{-1}$

where $\mathrm{W}_{\mathrm{i}}$ and $\mathrm{W}_{\mathrm{f}}$ are initial and final mean wet weight in $\mathrm{g}$; TFI the total feed intake; FB and FI are final and initial fish biomass in $\mathrm{g}$; DPI the total dietary protein intake; TPG the total body protein gain.

Apparent retention rate (\%) of $\mathrm{P}$ and $\mathrm{N}$, and the amount of $\mathrm{P}$ and $\mathrm{N}$ retained and discharged into water as wastes (faecal + urinary + gill) by fish were evaluated according to Cho et al. (1994) as follow:

Apparent retention rate (ARR, \%) of $\mathrm{P}$ and $\mathrm{N}=100 \mathrm{x}\left(\mathrm{TN}_{\mathrm{f}}-\mathrm{TN}_{\mathrm{i}}\right) \mathrm{N}_{\text {supplied }}^{-1}(\mathrm{~g})$,

Nutrient $_{\text {supplied }}(\mathrm{NS}, \mathrm{g})=\mathrm{N}_{\text {feed }} \mathrm{x}$ TFI

Nutrient $_{\text {retained }}(\mathrm{NR}, \mathrm{g})=\mathrm{NS} \times \mathrm{ARR} \mathrm{x}$ $100^{-1}$

Total nutrient waste $(\mathrm{TN}$ or $\mathrm{TP}, \mathrm{g})=$ NS - NR

Where: $\mathrm{TN}_{\mathrm{f}}$ and $\mathrm{TN}_{\mathrm{i}}$ are the final and initial nutrient ( $\mathrm{P}$ or $\mathrm{N}$ ) body content in $(\mathrm{g})$; $\mathrm{N}_{\text {supplied }}$ the quantity in ( $\mathrm{g}$ ) of nutrient ( $\mathrm{P}$ or $\mathrm{N}$ ) content in the total food supplied; $\mathrm{N}_{\text {feed }}$ is the quantity of feed supplied.

During the experiment, very limited feed loss was observed. Since this amount was unknown, we assume for calculations that the amount lost is 0 . 
Table 1: Formulation and proximate composition of experimental diets.

\begin{tabular}{|c|c|c|c|c|c|c|}
\hline Diets & $\mathbf{A}_{\mathbf{0}}$ & $\mathbf{A}_{10}$ & $\mathbf{A}_{20}$ & $\mathbf{A}_{30}$ & $\mathbf{A}_{40}$ & $\mathbf{A}_{50}$ \\
\hline \multicolumn{7}{|l|}{ Ingredients $\left({\left.\mathrm{g} 100 \mathrm{~g}^{-1}\right)}\right.$} \\
\hline Fish meal & 30 & 25 & 20 & 15 & 10 & 5 \\
\hline Azolla meal & 0 & 10 & 20 & 30 & 40 & 50 \\
\hline Cottonseed meal & 30 & 30 & 30 & 30 & 30 & 30 \\
\hline Maize bran & 18 & 17 & 16 & 15 & 14 & 10 \\
\hline Brewery draff & 20 & 16 & 12 & 8 & 4 & 3 \\
\hline Binder ${ }^{*}$ & 1 & 1 & 1 & 1 & 1 & 1 \\
\hline Salt $(\mathrm{NaCl})$ & 1 & 1 & 1 & 1 & 1 & 1 \\
\hline \multicolumn{7}{|c|}{ Proximate biochemical composition ${ }^{¥}$} \\
\hline Dry matter (\%) & 90.3 & 90.2 & 91.1 & 89.4 & 90.5 & 90.3 \\
\hline Crude protein (\% DM) & 29.3 & 29.3 & 29.2 & 29.1 & 29.2 & 29.0 \\
\hline Crude lipid (\% DM) & 10.8 & 10.0 & 9.4 & 9.0 & 8.4 & 8.0 \\
\hline Crude ash (\% DM) & 14.3 & 13.8 & 12.5 & 12.2 & 10.9 & 10.0 \\
\hline Crude fibre $^{\S}(\% \mathrm{DM})$ & 9.9 & 10.0 & 10.2 & 10.4 & 10.5 & 10.8 \\
\hline $\mathrm{NFE}^{\dagger}(\% \mathrm{DM})$ & 35.7 & 36.8 & 38.7 & 39.4 & 41.0 & 42.2 \\
\hline Gross energy $\mathrm{y}^{\ddagger}\left(\mathrm{kJ} \mathrm{g}^{-1}\right)$ & 17.0 & 16.9 & 16.9 & 16.9 & 17.0 & 17.0 \\
\hline Phosphorus (\% DM) & 1.13 & 1.08 & 1.06 & 1.00 & 0.95 & 0.76 \\
\hline $\begin{array}{l}\text { "Cassava starch, obtained a } \\
{ }^{\prime} \text { a Means of two analyses val } \\
{ }^{8} \text { Calculated according to C } \\
\text { filiculoides, respectively. } \\
\text { "Nitrogen-Free Extract, cal } \\
\text { "According to Tacon (1990 } \\
\text { DM: dry matter. }\end{array}$ & $\begin{array}{l}\text { cessing } \\
\text { Depot, }\end{array}$ & bought $\mathrm{i}$ & al mark & $\begin{array}{l}\text { eonard } \\
\text { fibre) }\end{array}$ & & \\
\hline
\end{tabular}

\section{Statistical analysis}

Data for growth, carcass composition and nutrient waste evaluation were analyzed using one-way analysis of variance (ANOVA). Differences between means were determined by Duncan's Multiple Range test (Duncan, 1955) to identify the differences among the triplicate groups at $P=0.05$. Before analysis, homogeneity of variance was checked using the "Hartley test" (Hartley, 1959). Ratios and percentage data were logtransformed. All analysis were done using SPSS program version 13.0 (SPSS, Chicago, Illinois, USA).

\section{RESULTS}

\section{Survival, growth rate and feed utilization}

As shown in Table 2, survival rate (range: $89.04 \%-93.3 \%$ ) did not show any significant differences and values were higher in each treatment $(P>0.05)$. Fish growth rate decreased significantly when AM level exceeded $10 \%$ in the $\operatorname{diet}(P<0.05)$. No significant differences were found in growth rate (range: $0.38-0.80 \mathrm{~g} \mathrm{day}^{-1}$ ) and specific growth rate (range: $1.26-1.87 \%$ day $^{-1}$ ) between fish fed with the control diet and those fed with diets containing $10 \%$ of AM. FCR increased from $1.44 \pm 0.03$ to $2.35 \pm 0.14$, with differences being significant at AM level exceeding $20 \%$ in diets $(P<0.05)$. Apparent net protein utilization decreased as AM increased, with significant differences between groups of diets containing more than $20 \%$ of AM $(P<0.05)$.

\section{Body composition of fish and nutrient retention}

No significant differences were found 45 
fresh matter) and body P (range: 0.62-0.68\% dry matter) content among fish fed with all the experimental diets $(P>0.05)$. Total $\mathrm{P}$ or $\mathrm{N}$ supplied with feed varied among dietary treatment (Table 3). TP and TN supplied decreased as AM increased in the diets, from $62.5 \pm 2.0$ to $33.4 \pm 1.4$ for TP and from $259.4 \pm 8.5$ to $203.7 \pm 8.8$ for $\mathrm{TN}(P<0.05)$. The nutrient output as wastes decreased significantly with increasing AM in diets $(P<$ 0.05). The evaluation as percentage of the amount supplied show no significant difference for TP $(P>0.05)$, whereas TN increased from $69.5 \%$ to $80.7 \% \quad(P<0.05)$ when dietary AM increased from $0 \%$ to $50 \%$, with significant difference when AM was greater than $20 \%$.

\section{DISCUSSION}

In the present study, the high survival rate indicates that experimental conditions are within the acceptable range for the production of Nile tilapia. Values obtained are comparable to those reported by AbdelTawwab and Ahmad (2009) in tanks while they are greater than the findings of Abou et al. (2007a, 2007b) in ponds. The growth performances namely the SGRs are better than the values reported by Garduño-Lugo and Olvera-Novoa (2008) when finding Nile tilapia with peanut (Arachis hypogea L.) leaf as a partial replacement of dietary FM. Our results indicate that $\mathrm{AM}$ could be used at upto $10 \%$ in diets without affecting fish growth. The decrease in growth performance when AM level was greater than $10 \%$ agreed with Fasakin et al. (2001) and Garduño-Lugo and Olvera-Novoa (2008) who reported a decline in growth rate when Azolla Africana L. and Arachis hypogea were used as FM partial replaces in $O$. niloticus diets. The main causative factor here could be the relative low digestibility of $\mathrm{AM}$ in $O$. niloticus and consequent lower nutrient availability in diets with high level of AM, as only $71.3 \%$ of protein in that fern is digestible (Micha and
Leonard, 2001-2), which is lower than the rate of about $90-92 \%$ generally reported for FM in this fish species (Sklan et al., 2004).

There are many dietary effects on crude protein and $\mathrm{P}$ levels in all experimental fish carcasses. These results agreed with findings reported in Nile tilapia by GarduñoLugo and Olvera-Novoa (2008) in floating cages and Schneider et al. (2004) in aquaria. These last authors did not find significant differences in fish body $\mathrm{P}$ when feeding Nile tilapia in aquaria with plant-based diets (with $0.19-2 \%$ P content) as substitutes. According to Schneider et al. (2004), the digestibility of phosphorus from plant-based diets in $O$. niloticus is generally higher than that of FMdiets; and Leonard et al. (1998) have found values ranging from 71.0 to $89.3 \%$ for digestibility coefficient of phosphorus from $A$. filiculoides in Oreochromis aureus, a species close to O. niloticus. But because of the high gastric acidity of Nile tilapia (Moreau, 1988) and the physiological response of fish that tend to keep nutrient to the minimum requirement, higher excess soluble $\mathrm{P}$ could be generated from the control diet and of which high amounts could be rapidly eliminated. So, little difference may occur in terms of quantity between the low available $\mathrm{P}$ extracted from the diets $\mathrm{A}_{0}$ and the relatively high available $\mathrm{P}$ from AM-diets (which contained lower dietary P); this could lead to assimilation of a similar quantity of $\mathrm{P}$ by all types of fish. Such findings have been reported in rainbow trout by Nakashima and Leggett (1980).

From the environmental point of view, TP waste expressed as the percentage of TP supplied show unexpectedly similar results. This contrasts with Jahan et al. (2003), and Kaushik et al. (2004) who found a reduction in $\mathrm{P}$ discharge when feeding fish with diets containing lower $\mathrm{P}$, in which $\mathrm{FM}$ was replaced by corn gluten meal. As there is no data on $\mathrm{P}$ discharge as a consequence of feeding Nile tilapia with Azolla, investigations must be continued to precise the effect of 
Y. ABOU et al. / Int. J. Biol. Chem. Sci. 4(1): 42-50, 2010

Table 2: Growth, feed performance and body composition of Nile tilapia fed in concrete tanks with Azolla-diets. Data are mean \pm S.D. of three replicates.

\begin{tabular}{|c|c|c|c|c|c|c|c|}
\hline Diets & $\mathbf{A}_{0}$ & $\mathbf{A}_{10}$ & $\mathbf{A}_{20}$ & $\mathbf{A}_{30}$ & $\mathbf{A}_{40}$ & $\mathbf{A}_{50}$ & \\
\hline Initial weight $(\mathrm{g})$ & $16.4 \pm 0.0$ & $16.4 \pm 0.0$ & $16.4 \pm 0.0$ & $16.4 \pm 0.0$ & $16.4 \pm 0.0$ & $16.4 \pm 0.0$ & \\
\hline Final weight $(\mathrm{g})$ & $88.3 \pm 2.0^{\mathrm{a}}$ & $84.8 \pm 3.5^{\mathrm{a}}$ & $78.4 \pm 1.8^{\mathrm{b}}$ & $68.2 \pm 2.1^{\mathrm{c}}$ & $60.2 \pm 1.3^{\mathrm{d}}$ & $51.0 \pm 2.4^{\mathrm{e}}$ & \\
\hline Growth rate $\left(\mathrm{g}\right.$ day $\left.^{-1}\right)$ & $0.80 \pm 0.02^{\mathrm{a}}$ & $0.76 \pm 0.04^{\mathrm{a}}$ & $0.69 \pm 0.02^{\mathrm{b}}$ & $0.58 \pm 0.02^{\mathrm{c}}$ & $0.49 \pm 0.01^{\mathrm{d}}$ & $0.38 \pm 0.03^{\mathrm{e}}$ & \\
\hline Specific growth rate $\left(\%\right.$ day $\left.^{-1}\right)$ & $1.87 \pm 0.02^{\mathrm{a}}$ & $1.82 \pm 0.05^{\mathrm{a}}$ & $1.74 \pm 0.03^{\mathrm{b}}$ & $1.58 \pm 0.03^{\mathrm{c}}$ & $1.44 \pm 0.02^{\mathrm{d}}$ & $1.26 \pm 0.05^{\mathrm{e}}$ & \\
\hline Survival (\%) & $91.1 \pm 1.9$ & $89.4 \pm 2.6$ & $91.7 \pm 4.4$ & $90.6 \pm 4.2$ & $91.7 \pm 1.7$ & $93.3 \pm 3.3$ & \\
\hline FCR & $1.44 \pm 0.03^{\mathrm{a}}$ & $1.49 \pm 0.03^{\mathrm{a}}$ & $1.56 \pm 0.06^{\mathrm{a}}$ & $1.79 \pm 0.10^{\mathrm{b}}$ & $1.98 \pm 0.05^{\mathrm{c}}$ & $2.35 \pm 0.14^{\mathrm{d}}$ & \\
\hline Apparent net protein utilization (\%) & $36.1 \pm 3.1^{\mathrm{a}}$ & $35.6 \pm 5.2^{\mathrm{a}}$ & $34.0 \pm 4.0^{\mathrm{a}}$ & $31.9 \pm 0.9^{\mathrm{a}}$ & $25.8 \pm 1.8^{\mathrm{b}}$ & $26.0 \pm 3.6^{\mathrm{b}}$ & \\
\hline Body composition $(\%)$ & & & & & & & Initial \\
\hline Crude protein (\% fresh matter) & $12.3 \pm 0.9$ & $12.2 \pm 0.3$ & $12.3 \pm 0.7$ & $12.0 \pm 0.5$ & $12.2 \pm 0.6$ & $12.1 \pm 0.9$ & $10.2 \pm 0.0$ \\
\hline Phosphorus (\% dry matter) & $0.65 \pm 0.03$ & $0.65 \pm 0.05$ & $0.68 \pm 0.06$ & $0.65 \pm 0.09$ & $0.64 \pm 0.04$ & $0.62 \pm 0.06$ & $0.40 \pm 0.01$ \\
\hline
\end{tabular}

${ }_{a, b, c, d, e,}$ In each line, means with no letters or with the same letters as superscripts are not significantly different $(P>0.05)$.

Table 3: Phosphorus and nitrogen balances in Nile tilapia fed Azolla. Data are mean \pm S.D. of three replicates.

\begin{tabular}{|c|c|c|c|c|c|c|}
\hline Diets & $\mathbf{A}_{0}$ & $\mathbf{A}_{10}$ & $\mathbf{A}_{20}$ & $\mathbf{A}_{30}$ & $\mathbf{A}_{40}$ & $\mathbf{A}_{50}$ \\
\hline P supplied $\left(\mathrm{g} \operatorname{tank}^{-1}\right)$ & $62.5 \pm 2.0^{\mathrm{a}}$ & $57.1 \pm 2.8^{b}$ & $55.0 \pm 3.1^{\mathrm{b}}$ & $48.7 \pm 1.6^{\mathrm{c}}$ & $43.8 \pm 1.1^{\mathrm{d}}$ & $33.4 \pm 1.4^{\mathrm{e}}$ \\
\hline $\mathrm{N}$ supplied $\left(\mathrm{g} \operatorname{tank}^{-1}\right)$ & $259.4 \pm 8.5^{\mathrm{a}}$ & $248.0 \pm 12.2^{\mathrm{a}}$ & $242.6 \pm 13.5^{\mathrm{ab}}$ & $226.6 \pm 7.5^{\mathrm{bc}}$ & $215.5 \pm 5.6^{\mathrm{cd}}$ & $203.7 \pm 8.8^{\mathrm{d}}$ \\
\hline $\mathrm{P}$ retention rate $(\%)$ & $9.94 \pm 0.63$ & $9.99 \pm 1.02$ & $10.4 \pm 1.0$ & $9.30 \pm 1.64$ & $8.85 \pm 0.45$ & $8.87 \pm 0.83$ \\
\hline $\mathrm{N}$ retention rate $(\%)$ & $30.5 \pm 2.8^{\mathrm{a}}$ & $29.4 \pm 1.2^{\mathrm{a}}$ & $28.3 \pm 2.4^{\mathrm{a}}$ & $24.4 \pm 0.4^{\mathrm{b}}$ & $22.6 \pm 1.8^{\mathrm{b}}$ & $19.3 \pm 1.1^{\mathrm{c}}$ \\
\hline$P$ retained $\left(\mathrm{g} \operatorname{tank}^{-1}\right)$ & $6.22 \pm 0.44^{\mathrm{a}}$ & $5.72 \pm 0.84^{\mathrm{a}}$ & $5.73 \pm 0.46^{\mathrm{a}}$ & $4.54 \pm 0.90^{\mathrm{b}}$ & $3.87 \pm 0.10^{\mathrm{bc}}$ & $2.97 \pm 0.40^{\mathrm{c}}$ \\
\hline $\mathrm{N}$ retained $\left(\mathrm{g} \mathrm{tank}^{-1}\right)$ & $79.2 \pm 9.1^{\mathrm{a}}$ & $73.0 \pm 5.4^{\mathrm{a}}$ & $68.8 \pm 9.1^{\mathrm{a}}$ & $55.4 \pm 2.5^{\mathrm{b}}$ & $48.8 \pm 4.9^{\mathrm{bc}}$ & $39.3 \pm 3.7^{\mathrm{c}}$ \\
\hline Total P waste $\left(\mathrm{g} \operatorname{tank}^{-1}\right)$ & $56.3 \pm 1.9^{\mathrm{a}}$ & $51.4 \pm 2.1^{\mathrm{b}}$ & $49.3 \pm 3.1^{\mathrm{b}}$ & $44.1 \pm 1.2^{\mathrm{c}}$ & $40.0 \pm 1.2^{\mathrm{d}}$ & $30.4 \pm 1.0^{\mathrm{e}}$ \\
\hline Total $\mathrm{N}$ waste $\left(\mathrm{g} \operatorname{tank}^{-1}\right)$ & $180.2 \pm 5.5^{\mathrm{a}}$ & $174.9 \pm 8.1^{\mathrm{ab}}$ & $173.8 \pm 6.5^{\mathrm{ab}}$ & $171.2 \pm 5.2^{\mathrm{b}}$ & $166.7 \pm 2.5^{\mathrm{b}}$ & $164.4 \pm 5.8^{b}$ \\
\hline Total P waste (\% supplied) & $90.1 \pm 0.6$ & $90.0 \pm 1.0$ & $89.6 \pm 1.0$ & $90.7 \pm 1.6$ & $91.2 \pm 0.4$ & $91.1 \pm 0.8$ \\
\hline Total $\mathrm{N}$ waste (\% supplied) & $69.5 \pm 2.8^{\mathrm{a}}$ & $70.6 \pm 1.2^{\mathrm{a}}$ & $71.7 \pm 2.4^{\mathrm{a}}$ & $75.6 \pm 0.4^{\mathrm{b}}$ & $77.4 \pm 1.8^{\mathrm{bc}}$ & $80.7 \pm 1.1^{\mathrm{c}}$ \\
\hline
\end{tabular}

$\overline{a, b, c, d, e, I n}$ each line, means with no letters or with the same letters as superscripts are not significantly different $(P>0.05)$. 
Azolla in low-polluting fish-feed. In contrary, TN waste increased with increasing AM in the diets, as a consequence of the relative lower digestibility of protein from the fern and the high digestibility and assimilation of that providing from FM. This probably cause the reduction of fish growth as explained above, consistency with Jahan et al. (2003) who stated that growth reflects the FCR and a better FCR indicates a lower discharge of unassimilated nutrient, and with Ballestrazzi et al. (1994) and Bergheim et al. (1996) who reported that FCR and nutrients released into the water partially depend on fish size and the type of culture system.

\section{Conclusion}

Based on the findings from this study, AM could be used at upto $10 \%$ in diets without adverse effects on growth performance. In low-polluting feed field however, further investigations must be implemented to formulate AM-diets that sustain growth while reducing $\mathrm{P}$ wasted by fish. Positively however, the undigested nitrogen from high AM-feed (AM level superior to $20 \%$ ) is wasted and provided to water, which will be quite good in tropical marshland ponds where nitrogen is already limiting.

\section{ACKNOWLEDGEMENTS}

The research was funded by the General Direction for Development Cooperation of Belgium (DGCD/BTC) and FUNDP-University of Namur (Belgium). We wish to thank Mrs Gersande Blanchard and Emilie Henrote of URBO/FUNDP and $\mathrm{Mr}$ Sébastien Steels and Mrs Christelle Boudry of 'Faculté Universitaire des Sciences Agronomiques de Gembloux (Unité de Zootechnie)' for their technical assistance.

\section{REFERENCES}

Abou Y, Fiogbé ED, Micha JC. 2007a. A preliminary assessment of growth and production of Nile tilapia, Oreochromis niloticus L., fed Azolla-based-diets in earthen ponds. Journal of Applied Aquaculture, 19(4): 55-69.

Abou Y, Fiogbé ED, Micha JC. 2007b. Effects of stocking density on growth, yield, and profitability of farming Nile tilapia, Oreochromis niloticus L., fed Azolla-diet, in earthen ponds. Aquaculture Research, 38: 595-604.

Abdel-Tawwab M, Ahmad MH. 2009. Live Spirulina (Arthrospira platensis) as a growth and immunity promoter for Nile tilapia, Oreochromis niloticus (L.), challenged with pathogenic Aeromonas hydrophila. Aquaculture Research, 40: 1037-1046.

Afuang W, Siddhuraju P, Becker K. 2003. Comparative nutritional evaluation of raw, methanol extracted residues and methanol extracts of moringa (Moringa oleifera Lam.) leaves on growth performance and feed utilization in Nile tilapia (Oreochromis niloticus L.). Aquaculture Research, 34: 1147-1159.

AOAC. 1990. Official Methods of Analysis $\left(15^{\text {th }}\right.$ edn). Association of Official analytical chemists: Arlington, VA, USA.

Ballestrazzi R, Lanaagarao E, Mion A. 1994. The effect of dietary protein level and source on growth, body composition, total ammonia and relative phosphate excretion of growing sea bass (Dicentrarchus labrax). Aquaculture, 127: 197-206.

Bergheim A, Åsgård T. 1996. Waste production in aquaculture. In Aquaculture and Water Resource Management, Baird, DJ, Beveridge MCM, Kelly LA, Muir JF (eds). Blackwell Science: Oxford; 50-80.

Cho CY, Hynes JD, Wood KR, Yoshida HK. 1994. Development of high-nutrientdense, low-pollution diets and prediction of aquaculture waste using biological approaches. Aquaculture, 124: 293-305.

Cho CY, Bureau DP. 1997. Reduction of waste output from salmonid aquaculture 
trough feed and feeding. The Progressive Fish-Culturist, 59: 155-160.

Cho CY, Bureau DP. 2001. A review of diet formulation strategies and feeding systems to reduce excretory and feed wastes in aquaculture. Aquaculture Research, 32: 349-360.

Duncan DB. 1955. Multiple range and multiple F-tests. Biometrics, 11: 1-42.

Fasakin EA, Balogun AM, Fagbenro OA. 2001. Evaluation of Sun-Dried water fern, Azolla africana, and Duckweed, Spirodela polyrrhiza, in practical diets for Nile Tilapia, Oreochromis niloticus, Fingerlings. Journal of Applied Aquaculture, 11(4): 83-92.

Fiogbé ED, Micha JC, Van-Hove C. 2004. Use of a natural aquatic fern, Azolla microphylla, as a main component in food for Omnivorous-phytoplanktonophagous tilapia, Oreochromis niloticus L. Journal of Applied Ichthyology, 20: 517-520.

Folch J, Lees M, Sloane-Stanley GHS. 1957. A simple method for the isolation and purification of total lipids from animal tissues. Journal of Chemistry, 226: $497-$ 509.

Garduño-Lugo M, Olvera-Novoa Á. 2008. Potential of the use of peanut (Arachis hypogea) leaf meal as a partial replacement for fish meal in diets for Nile tilapia (Oreochromis niloticus L.). Aquaculture Research, 39: 1299-1306.

GESAMP. 1996. IMO/FAO/UNESCO-IOC/ WMO/WHO/IAEA/UN/UNEP (Joint Group of Experts on the Scientific Aspects of Marine Environmental Protection). Monitoring the Ecological Effects of Coastal Aquaculture Wastes. GESAMP, Rome.

Gross A, Boyd CE. 1998. A digestion procedure for the simultaneous determination of total nitrogen and total phosphorus in pond water. Journal of the World Aquaculture Society, 29: 300-303.

Hardy RW. 2000. New developments in aquatic feed ingredients, and potential of enzyme supplements. In: Cruz-Suarez, L.E., Ricque-Marie, D., Tapia-Salazar, M., Olvera-Novoa, M.A., CiveraCerecedo, R., (Eds.), Advances en Nutricion Acuicola V. Memorias del V Simposium Internacional de Nutricion Acuicola. 19-22 November, 2000, Merida, Yucatan, Mexico.

Hartley HO. 1959. Smallest composite designs for quadratic response surface. Biometrics, 15: 611-624.

Jahan P, Watanabe T, Satoh S, Kiron V. 2003. Reduction in elemental waste loading from commercial carp feeds by manipulating the dietary phosphorus levels. Fisheries Science, 69: 58-65.

Kaushik SJ, Covès D, Dutto G, Blanc D. 2004. Almost total replacement of fish meal by plant protein sources in the diet of a marine teleost, the European seabass, Dicentrarchus labrax. Aquaculture, 230: 391-404.

Leonard V. 1997. Use of an aquatic fern (Azolla filiculoides) in two species of tropical fish (Oreochromis niloticus and Tilapia rendalli). Doctoral dissertation, Catholic University of Louvain, Louvainla-Neuve, Belgium.

Leonard V, Breyne C, Micha J.-C, Larondelle Y. 1998. Digestibility and transit time of Azolla filiculoides Lamarck in Oreochromis aureus (Steindachner). Aquaculture Research, 29: 159-165.

Mélard Ch. 1986. Bases biologiques de l'élevage intensif du Tilapia du Nil $O$. niloticus. Cahiers d'Ethologie Appliquée, 5(3): 1-224.

Micha JC, Leonard V. 2001-2. Digestibility of the aquatic fern Azolla filiculoides Lamarck in two species of tilapia: The phytoplanktonophagous Oreochromis niloticus (L.) and the macrophytophagous Tilapia rendalli (Boulenger). Bulletin des Séances de l'Académie Royale des Sciences d'Outre-Mer, 47: 147-157.

Moreau Y. 1988. Physiology de la digestion. In Biologie et Ecologie des Poissons 
d'Eau Douce Africain, Levêque C, Bruton MN, Ssentongo GW (eds). Coll. Travaux et Documents 216, ORSTOM: Paris; 137-152.

Nakashima BS, Leggett WC. 1980. Natural sources and requirements of phosphorus for fishes. Canadian Journal of Fisheries and Aquatic Sciences, 37: 679-686.

Ogino C, Takeuchi L, Takeda H, Watanabe T. 1979. Availability of dietary phosphorus in carp and rainbow trout. Nippon Suisan Gakkaishi, 45: 1527-1532.

Schneider O, Amirkolaie AK, Vera-Cartas J, Eding EpH, Schrama JW, Verreth JAJ. 2004. Digestibility, faeces recovery, and related carbon, nitrogen and phosphorus balances of five feed ingredients evaluated as fishmeal alternatives in Nile tilapia, Oreochromis niloticus L. Aquaculture Research, 35: 1370-1379.
Sklan D, Prag T, Lupatsch I. 2004. Apparent digestibility coefficients of feed ingredients and their prediction in diets for tilapia Oreochromis niloticus $\mathrm{x}$ Oreochromis aureus (Teleostei, Cichlidae). Aquaculture Research, 35: 358-364.

Steffens W. 1989. Principles of Fish Nutrition. Halsted Press: New York.

Tacon AGJ. 1990. Standard Methods for the Nutrition and Feeding of Farmed Fish and Shrimp. Argent Laboratories Press: Washington, DC, USA, 454pp.

Zhang S, Xie S, Zhu X, Lei W, Yang Y, Zhao M. 2006. Meat and bone meal replacement in diets for juvenile gibel carp (Carasius auratus gibelio): effects on growth performance, phosphorus and nitrogen loading. Aquaculture Nutrition, 12: 353-362. 